\title{
Intermestic Approach Implementation in International Regime Learning Process through Group Investigation Cooperative Model
}

\author{
Anita Afriani Sinulingga ${ }^{1, *}$, Putiviola Elian Nasir ${ }^{2}$ \\ 1, 2 International Relations Department, Faculty of Social and Political Sciences, Andalas University, Limau \\ Manis, Padang, West Sumatra 25163, Indonesia \\ *Corresponding author. Email: anitaafriani@soc.unand.ac.id
}

\begin{abstract}
The purpose of this article is to describe students' learning outcomes after the development of group investigation type, cooperative learning method, in the International Regime course. The application of this method through intermestic approach is expected to contribute to the image of international relations study to be more grounded. The focus of this approach is the interconnection between the international system and the political, economic, social and cultural dynamics in the domestic sphere. In learning this subject, it analyzes the implementation of various international regimes that apply in Indonesia, West Sumatra and Padang in particular. This type of research is a classroom action research with six stages, namely grouping, planning, investigating, organizing, presenting and evaluating. The development of this learning model was conducted for 48 students of the 6th semester (year 2018). The results showed that applying the group investigation model helped achieve the learning objectives of the course. The performance assessment method discovered an increase in student learning outcomes in the International Regime course.
\end{abstract}

Keywords: Cooperative Learning, Group Investigation, Performance Assessment

\section{INTRODUCTION}

A common understanding for both the public and new students in the Department of International Relations (IR), is that IR is the study of global events or events that occur in countries Indonesia's outside cross- border jurisdiction so that the effects or benefits of these events do not have consequences for Indonesian society. International events are understood to only affect government policies at the national level, and do not touch people and individuals in their daily lives. In addition, this study is considered insignificant for people in developing countries like Indonesia, but for consumption of people in developed countries (1). Therefore, this research attempts to develop an intermestic (international-domestic) approach in the International Regime course. This course is designed as a practicum course aimed at developing students' critical thinking in developing IR research by applying an intermestic approach.

In general, lectures apply the SCL (Student
Centered Learning) learning method by combining lecture methods, small group discussions, assignments and presentations (2). This course's learning materials are lecture handouts equipped with teaching materials such as powerpoints. All lecture materials, assignments and their assessments are collected through Andalas University online learning system. Learning outcomes evaluation is adjusted to the learning method and is classified into formative and summative evaluation. Formative assessment is through individual assignments and group assignments with $30 \%$ score weight each. Meanwhile, summative evaluation is through semester exam at the middle and end of the semester with $20 \%$ score weight each. Previously, the RPS was delivered and discussed with students at the beginning of the lecture.

However, there are still several problems in the learning process of this course even after applying the SCL method. First, some students tend to be passive, although some are very active and responsive in lectures. For these students, it 
was difficult in ensuring their understanding of the lecture, especially because this course was very theoretical and methodological. Second, the desire to discover new knowledge and insights is still low. Students only depend on the lecture materials. Students tend to be lazy to read, evaluated from the sources quoted in lecture assignments (online news media). In addition, the results of student learning evaluations are not satisfactory. Even though $90 \%$ of students pass this course, only about $36 \%$ of students achieved maximum grade $(\mathrm{A})$.

\section{OUTPUT ACHIEVEMENT STRATEGY}

The first strategy to solve the problem describes the intermestic approach in the study of international relations. Before explaining the form of learning media development and learning evaluation methods, it is important to explain the internationaldomestic dimensions in the International Regime course. Departing from the objectives and learning evaluation, the second part explains the development of cooperative learning methods with the type of group investigation. In the third part, this section describes the development of learning evaluation methods through performance assessment as an alternative form of assessment.

\subsection{Intermestic Approach in International Relations}

Putnam's thought titled "The Logic of Two Level Game" explains that conditions which occur at the domestic level are influenced by international conditions, likewise, domestic conditions that occur within the jurisdiction of a country have significant influence on international conditions or global trends (3). Efforts to make IR studies more grounded can be explained by an intermestic approach which is a combination of international and domestic. This approach is a relatively new approach about how the international system affects domestic phenomena consisting of issues, policies, or norms / ideas. With international influence, this allows researchers, observers and practitioners of international relations to apply their knowledge in everyday life because in the era of globalization, international influence has even entered private spaces through increasingly sophisticated information and communication technology (4).

Globalization that encourages integration economically, politically and culturally gives rise to intermesticity between the international and domestic systems, for example through cross-border flows of trade, capital and human beings (Held and McGrew, 2002 in (5). Through this approach, IR scholars, including students, become more concerned with domestic issues, policies and ideas / norms while still relating them to what is happening in the international world. Likewise, domestic political researchers are expected to broaden their perspective by not only looking at domestic matter factors (5 p. 14).

\subsection{Cooperative Learning Methods Development with Group Investigation Type}

This research is an educational development research by the Department of International Relations, Faculty of Social and Political Sciences, Andalas University in 2020. The object of research is International Regime course students (48 people). The research involved three lecturers with roles as planning, implementing, observing and evaluating the research.

The level of approach success criteria in this study is observed from the increase in student's ability to understand intermestic studies in IR study in each cycle, and the level of learning success achievement is a value of $\geq 75$ with a minimum of $60 \%$ of the student population. If the indicators of success in student understanding and skills have been achieved, the research is stopped.

Cooperative learning comes from the word cooperative, which means working together by helping each other as a group or as a team. Slavin in (6) suggests "In cooperative learning methods, students work together in four member teams to master material initially presented by the teacher". This description argues that cooperative learning works in small groups of 4-6 people collaboratively in order to stimulate students to be more passionate about learning. By implementing the cooperative learning model, students are able to achieve success in learning, in addition, they can also train students to have both thinking and social skills, such as skills for expressing opinions, receiving suggestions and input from other people, cooperate, feel loyal to friends, and reduce the incidence of deviant behavior in class life. (Stahl in (6 p. 23).

There are many variations of cooperative learning methods, one of which is the Group Investigation (GI) type. The reason for using this model for classroom action research is because Group investigation is a complex model of cooperative learning combining the principles of cooperative learning with constructivism- based learning and democratic learning principles. This model can train students to develop independent thinking skills (7).

Group learning requires students to use higherlevel thinking skills. According to Killen in (8), the main characteristics of the GI cooperative learning type is: 
1. Students work in small groups under lecturer guidance.

2. Student activities focus on efforts to answer formulated questions.

3. Student learning activities always require them to collect, analyze and conclude data.

The GI type of cooperative learning model goes through the following stages (9). The cycle of implementing the GI type of cooperative learning model can be seen in Figure 3:

1. Grouping. Activities at this stage are identifying topics and organizing them into each working group:

a. Students quickly read various sources, submit topics and organize suggestions,

b. Students join groups that are studying their chosen topic,

c. The group composition is based on interest and is heterogeneous

d. Lecturers help and gather information and facilitate organization.

2. Planning. At this stage students plan investigations in groups decide division of labor.

3. Investigating. Activities at this stage:

a. Students collect information, analyze data and reach conclusions.

b. Each group member contributes to the group effort.

c. Students exchange, discuss, explain and synthesize ideas.

4. Organizing. Research activities at this stage include:

a. Group members determine important things from learning materials.

b. Group members plan what they report how they make their presentation.

c. Group representatives form a committee to coordinate plans for presentations.

5. Presenting. The stages in this research are as follows:

a. Presentations are made to the whole class in various forms.

b. The presentation section must involve the audience (audience) actively.

c. The audience evaluates the clarity and attractiveness of the presentation according to predetermined criteria.

6. Evaluating. The activities at this last stage are:

a. Students exchange feedback on topics, about the work they are doing, and about their affective experiences.

b. Lecturers and students collaborate in evaluating student learning

c. Assessment of learning should evaluate higher level thinking.

As a part of the cooperative learning method, the group investigation type has proven to be effective in helping classrooms achieve their learning outcomes. There has been many publications reiterating the success of group investigation in different levels of education starting from elementary school (10), secondary school (11); (12) and senior high school (13), (14). However, literature related to its results in university education is still difficult to find. Thus this research will also be able to narrow this gap, contributing to strengthening the effectivity of group investigation in all levels of education.

\subsection{Development of Performance Assessment as a Learning Evaluation Method}

The use of GI type also allows the use of alternative assessments such as performance assessment in assessing student learning outcomes which is the lecturer's process in collecting information on the development and achievement of student learning through various techniques that are able to be proven or shown precisely that learning objectives have been truly mastered and achieved. Assessment or measurement of learning outcomes is the collection of relevant information that can be accounted for in the context of decision making. Although learning process in the classroom is in the form of student groups, its assessment and evaluation are conducted individually with appropriate and measurable methods (15).

Furthermore, this type of performance assessment attempts to improve and complement traditional assessment (test and non-test assessment) therefore incorporating learning process as part of assessment. On the other hand, Bloom (16) reminded that the assessment choice must be adjusted to the learning objectives following related to cognitive, affective, and psychomotor learning outcomes. The basic performance assessment activities (authentic assessment or performance assessment) are from assignments, students performance, and assessments based on certain indicators with an instrument called a rubric. Further explanation is illustrated in the performance assessment scheme in Figure 1.

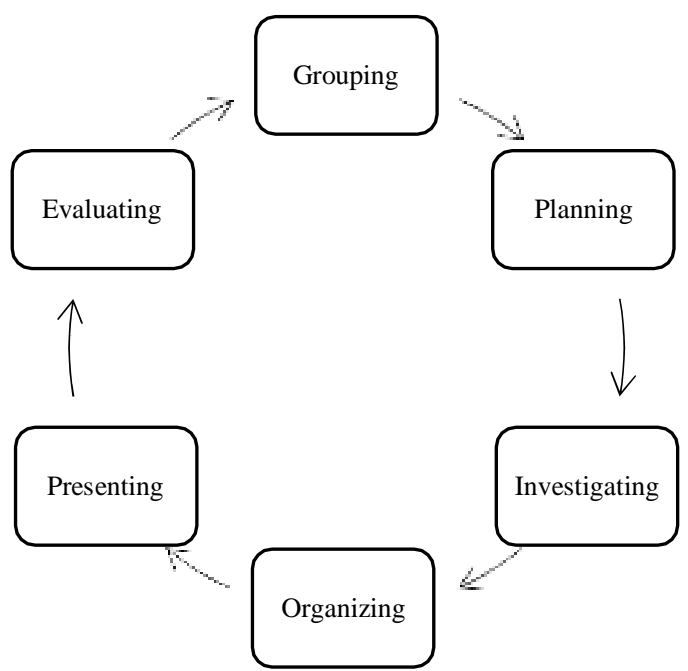

Figure 1. Cooperative Learning Model Type Group Investigation Cycle 
A rubric is an assessment guide that describes criteria used by lecturers in assessing student learning or work outcomes. Thus, the rubric contains a list of performance characteristics that are expected to materialize/ appear in student work processes and results, and serve as a guide for evaluating each of these characteristics. There are three types of rubrics: descriptive rubrics, holistic rubrics, and perceptual scale rubrics. In general, descriptive and holistic rubrics are often used in learning, while perceptual scale rubrics are mostly used for conducting research or surveys (15). This study used the holistic rubric because of its simpler format.

The holistic rubric has one score scale, which is the highest scale. The contents of the dimension description are the criteria of a performance for the highest scale. For students who do not meet these criteria, the assessor gives feedback related to their performance. This type of rubric demands consistency from the assessors, including the adequacy of the time needed for more assessments.

\section{RESULT AND DISCUSSION}

\subsection{Application of Group Investigation Learning Model in International Regime Subjects}

The Group Investigation type is applied through six stages and was assessed with the Authentic Assessment model. This assessment model is conducted by compiling assignment (Task) and assessment rubric (Rubric) by the lecturer (15). At the first meeting, lecturers and students agree on a Semester Learning Design (RPS), including the form of assignment which in general, are independent assignments and group assignments. For this course, students in group will have to compile interactive video containing analysis of the international regime implementation in West Sumatra (cities/ regencies). The learning and assessment model application in the International Regime course is explained in three parts: planning, implementation and evaluation. The entire learning process is uploaded to the Andalas University http://fisip.ilearn.unand.ac.id/course/view.php?id=1828. In the fifth week, students will be instructed to form their respective working groups. Of the 48 students, 10 groups were formed, each group consisting of 4-5 people. Group members were determined by each team while students who were not present at the time of group division will form new groups or distributed to other groups. There were five topics that were randomly distributed to each group: the halal tourism regime, climate change regime, human rights/ humanity, disaster management and international development.

In the next stage, each group create outlines developed based on the chosen topic, using the template already made by the lecturer. The outline is then submitted to the lecturer for suggestions and feedback.
In giving assessment, the lecturer prepares a holistic type rubric assessment. The assessment also involves other students in different groups (self-assessment), which leads to the integrity of student abilities both in terms of cognitive, affective and psychomotor. Group project presentations are conducted every week in sequence according to the order of learning topics starting after midterm exam. The following is the development of international regime topics compiled by students.

Adapting to the spread of Covid-19, class project video presentations including discussions were conducted through the LMS Unand Ilearn platform. Each week, there were two groups presenting and two groups appointed as observers whose task was to compile presentation resume. Meanwhile, other students were asked to write their comments as well as proof of attendance. To ensure an organized learning and discussion, the lecturer arranges several drop boxes in Ilearn based on the necessity of each group. As an example of the learning process at the 11th meeting through the Ilearn view. At the final stage of the learning process, the lecturer conducts an assessment by quantifying students' abilities in this section; and evaluation by providing feedback and suggestions assignments for improvements. This group project contributes a maximum of $30 \%$ of the total student final score.

\subsection{Student Learning Outcomes through Cooperative Learning Type Group Investigation}

Assessment in this course is conducted during the learning process through group project presentation activities (30\%) and online class discussions, individual assignments midterm exams final exams. The application of this method it is to observe students' ability in in linking issues / trends, actors or global values with events and conditions of the international world to the domestic level. The student scores targeted in the application of this learning and assessment method are at least 75 in numerical values or A- in letter grades with a minimum of $60 \%$ of the student population. Student learning outcomes using group assignments in different academic years can be compared in Table 1 and Figure 2.

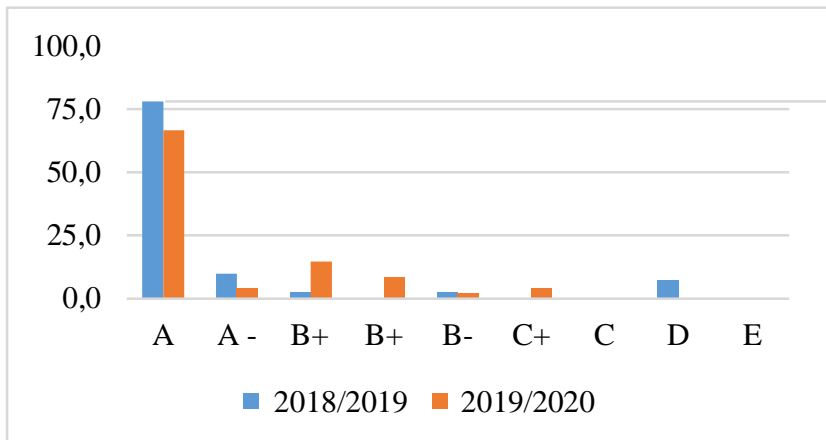

Figure 2. Comparison of Student Learning Outcomes through the Class Project 
Table 1. Comparison of Student Learning Outcomes through the Class Project

\begin{tabular}{|l|l|l|l|l|l|l|l|l|l|l|}
\hline \multirow{2}{*}{ Year } & \multicolumn{9}{|l|}{ Score Range } & $\begin{array}{l}\text { Number of } \\
\text { Students }\end{array}$ \\
\cline { 2 - 12 } & A & A- & B+ & B & B- & C+ & C & D & E & 41 \\
\hline $2018 / 2019$ & 32 & 4 & 1 & 0 & 1 & 0 & 0 & 3 & 0 & 48 \\
\hline $2019 / 2020$ & 32 & 2 & 7 & 4 & 1 & 2 & 0 & 0 & 0 & 48 \\
\hline
\end{tabular}

Although using different SCL methods, the table and figure above explain the student learning outcomes through group assignments in the International Regime class project in the two academic years show satisfactory results where students who get an $\mathrm{A}$ in their group project are more than $65 \%$.

Assessed media elements show students' ability in developing audiovisual media by $88.5 \%$, meaning good quality and high creativity media. The analysis aspect demonstrated students were able to achieve a score of $74 \%$, meaning having the ability to understand the scope of International Relations, International Regime and are able to reduce problems at the international level to the domestic realm. Students' knowledge of the topics and cases is reflected through the preparation of infographics based on their respective group projects. In this section, the ability of students to compile an interesting and easyto-understand infographic was $79.7 \%$.

During iLearn discussion and answering stage, students were asked to compile a summary, questions or criticisms after watching videos by other groups. Even though this section has the lowest points, its assessment percentage is satisfying, which is $72,6 \%$. The final assessment is the job description explanation where the indicator of this section is to evaluate students' ability in determining job descriptions and evenly distribute tasks. These methods were able to achieve the cognitive, affective and psychomotor realm of learning in the International Regime course.

In general, the outcome provided significant results compared to the results of student evaluation in the International Regime course that did not apply this method in the previous academic year. The following is a comparison table of student learning outcomes in the
International regime course in the 2018/2019 and 2019/2020 academic years.

The data in the table above shows that the distribution of students' final scores in the International Regime course in the current semester has increase in A and A- grades obtained by $62.5 \%$ of students, while in the previous academic year, the same score was reached by $51.2 \%$. The lowest scores obtained by students in the 2018/2019 academic year in this course were D and E scores with $9,8 \%$, compared to $0 \%$ of the same score in this current year which means all students passed the International Regime course of 2020. The increase in the distribution of students' final grades in the International Regime course with the cooperative model development method when compared to the acquisition of learning outcomes in the previous academic year shows that the group investigation learning model development method is effectively applied to the learning process.

Table 7 below explains the distribution of students who obtained the maximum score through group assignments was $66.7 \%$ but at the final grade of this course only $27.1 \%$ percent of students managed to get an A grade. This information confirms that the SCL method with the model group investigation type cooperative learning was appropriately used in learning, especially in this subject. However, the student's final score is a combination of various assessment components, in addition to group assignments there are independent assignments, final and midterm examinations. Therefore, it is important to consider appropriate learning evaluation methods for other components so that student learning outcomes can increase.

Table 2. Comparison of Student Learning Outcomes

\begin{tabular}{|c|l|l|l|l|l|l|l|l|l|l|}
\hline \multirow{2}{*}{ Year } & \multicolumn{1}{|l}{ Score Range } & $\begin{array}{l}\text { Number of } \\
\text { Students }\end{array}$ \\
\cline { 2 - 12 } & A & A- & B+ & B & B- & C+ & C & D & E & Student \\
\hline $2018 / 2019$ & 15 & 6 & 6 & 3 & 5 & 0 & 2 & 0 & 4 & 41 \\
\hline $2019 / 2020$ & 13 & 17 & 12 & 3 & 2 & 0 & 1 & 0 & 0 & 48 \\
\hline
\end{tabular}

Table 3. Comparison of Student Learning Outcomes Percentage

\begin{tabular}{|l|c|r|r|r|r|r|r|r|r|}
\hline \multirow{2}{*}{ Year } & \multicolumn{10}{c|}{ Score Average (in \%) } \\
\cline { 2 - 11 } & A & A- & B+ & B & B- & C+ & C & D & E \\
\hline $2018 / 2019$ & 36,6 & 14,6 & 14,6 & 7,3 & 12,2 & 0,0 & 4,9 & 0,0 & 9,8 \\
\hline $2019 / 2020$ & 27,1 & 35,4 & 25,0 & 6,3 & 4,2 & 0,0 & 2,1 & 0,0 & 0,0 \\
\hline
\end{tabular}




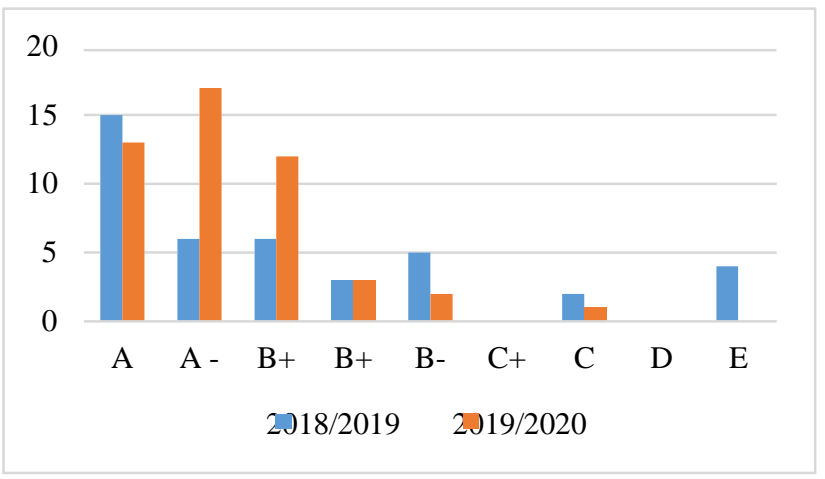

Figure 3. Comparison of Student Learning Outcomes

Table 4. Comparison of Percentage of Student Learning Outcomes at Group Assignment Components to Student's Final Score

\begin{tabular}{|l|l|l|l|l|l|l|l|l|l|}
\hline \multirow{2}{*}{$\begin{array}{l}\text { Year } \\
\mathbf{2 0 1 9 / 2 0 2 0}\end{array}$} & Score Range (in\%) \\
\cline { 2 - 11 } & A & A- & B+ & B & B- & C+ & C & D & E \\
\hline Group Assignment & 66,7 & 4,2 & 14,6 & 8,3 & 2,1 & 4,2 & 0,0 & 0,0 & 0,0 \\
\hline Final score & 27,1 & 35,4 & 25,0 & 6,3 & 4,2 & 0,0 & 2,1 & 0,0 & 0,0 \\
\hline
\end{tabular}

\section{CONCLUSION}

The learning method application with development of group investigation type cooperative learning method in the International Regime course was considered quite effective compared to the method previously applied to the same course. Through the application of performance assessment methods, student learning outcomes assessment can include various elements such as cognitive, affective and psychomotor elements. Thus meaning, the application of the SCL learning model is appropriate for this course. Based on the learning success target level, which is a value of $\geq 75$ with a minimum amount of $60 \%$ of the student population, it can be concluded that application of this method provides significant results on student learning outcomes. At the end of the course, there was an increase when compared to the previous assessment, where $62.5 \%$ of students obtained $\mathrm{A}$ and $\mathrm{A}$ - grades, while no students failed this course.

\section{REFERENCES}

[1] Bakry, Umar Suryadi. Dasar-dasar Hubungan Internasional. Depok : Kencana, 2017.

[2] LP3M. Panduan Praktis Pelaksanaan Student Centered Learning (SCL): Meningkatkan Interaksi Mahasiswa dan Dosen dalam Pembelajaran. Padang : Universitas Andalas, 2014.

[3] Diplomacy and Domestic Politics: The Logic of Two- Level Games. Putnam, Robert D. 3, s.1. : MIT Press, 1988, International Organization, Vol. 42, pp. 427-460.
[4] Pendekatan Intermestik dalam Proses Perubahan Kebijakan: Sebuah Review Metodologis. Kurniawati, Dyah Estu. 2, s.1. : Universitas Muhammadiyah Malang, Desember 2012, Jurnal Studi Hubungan Internasional, Vol. 2.

[5] Kusumaningrum, Demeiati N and Kurniawati, Dyah Estu. Intermestik sebagai Pendekatan Studi Hubungan Internasional: Pengantar dan contoh Penelitian. Yogyakarta: LeutikaPrio, 2016. p. 13.

[6] Isjoni. Cooperative Learning: Efektivitas Pembelajaran Kelompok. Bandung : Alfabeta, 2007. p. 15.

[7] Isjoni. Cooperative Learning: Mengembangkan Kemampuan Belajar Berkelompok. Bandung: Alfabeta, 2011. p. 87.

[8] Aunurrahman. Belajar dan Pembelajaran. Bandung: Alfabeta, 2010. p. 152.

[9] Asma, Nur. Model Pembelajaran Kooperatif. Jakarta : Departemen Pendidikan Nasional, Direktorat Jenderal Pendidikan Tinggi , 2006. p. 62.

[10] Application of Group Investigation Model to Increase Learning Outcomes of Elementary School Students. Yuanita, Rizki, Degeng, I Nyoman Sudana and Sudarmiatin. 1, 2018, Journal of K6, Education and Management, Vol. 1, p. 24.

[11] Effect of Cooperative Learning Model Type Group Investigation with Animation, Motivation on Students' Conceptual Knowledge Junior High School. Rajagukguk, Nurbaya, Bukit, Nurdin and Turnip, Betty 
Marisi. 21, 2017, Journal of Education and Practice, Vol. 8, pp. 41-47.

[12] Enhancing Cultural Sensitivity through Group Investigation- A Co-operative Learning Approach. Damini, Marialuisa and Surian, Alessio. 2, 2013, Journal of Cooperative Studies, Vol. 46, pp. 24-31.

[13] The Influence of Group Investigation (GI) Learning Model on Geography Learning Outcomes of SMA Negeri 1 Banjarbaru. Restu, Ulfa. 1, 2020, Journal Learning Geography, Vol. 1, pp. 32-35.

[14] The Application of Group Investigation Model in Circulation Learning System to Improve Students' Science Process Skills and Critical Thinking Abilities. Muhibbuddin, Sari, Tya Novenda and Khairil. 17, 2020, International E-Journal of Advances in Education (IJAEDU), Vol. 6, pp. 178-183.

[15] DIKTI. Alternative Assesment. Jakarta : Depdiknas, 2005.

[16] Bloom, Benjamin S. Taxonomy of Educational Objectives, Handbook: The Cognitive Domain. New York : David McKay, 1956. 